International Journal of Social Science And Human Research

ISSN(print): 2644-0679, ISSN(online): 2644-0695

Volume 05 Issue 02 February 2022

DOI: 10.47191/ijsshr/v5-i2-10, Impact factor-5.586

Page No: $447-450$

\title{
Effectiveness of International Documents on Bilateral International Cooperation of The Republic of Uzbekistan With The Gulf Countries
}

\author{
Dr. Mahinnora N. Mirkhamidova \\ Doctor of Philosophy in Law,Department of International Law and Human Rights of UNESCO, University of World Economy and \\ Diplomacy
}

\begin{abstract}
This article focuses on the realization of bilateral international agreements signed by the Republic of Uzbekistan with the Arab states in the Persian Gulf region (Kingdom of Saudi Arabia, United Arab Emirates, Sultanate of Oman, Kuwait and Qatar). At the same time, the agreements concluded between these countries since the independence of the Republic of Uzbekistan have been researched. The article notes that the investments made by the Arab Development Funds are mainly directed to improving infrastructure, construction and development of the economy sectors, and have shown effective results. In the concluding part of the article, the author makes proposals to strengthen the effectiveness of international agreements between Uzbekistan and the Gulf Arab states.
\end{abstract}

KEYWORDS: bilateral agreements, implementation of national legislation, efficiency mechanism, Arab development funds, Fund for Reconstruction and Development of the Republic of Uzbekistan, Kuwait Fund for Arab Economic Development.

\section{INTRODUCTION}

Over the years of independence, we have observed that the legal framework of cooperation relations of Uzbekistan has improved in various directions. It should be noted that the contractual legal framework of Uzbekistan's relations with the Gulf Arab states has developed in several directions. We consider it expedient to analyze the effectiveness mechanism of contracts in order to draw appropriate conclusions on the realization of these legal documents and their implementation in legislation.

According to the research conducted by the Russian scientist V.V. Gavrilov, the international and national legal systems should work in harmony and interconnectedness [1]. We also support the views of V.V. Gavrilov in this regard.

\section{THE MAIN PART}

It should be noted that the mechanisms of control over the realization of bilateral international agreements by national legislation are effectively implemented in Uzbekistan today.

Measures have been taken to improve the work of the Uzbek side of intergovernmental commissions (committees, councils and working groups) on bilateral cooperation between Uzbekistan and foreign countries [2].

According to its, in order to coordinate interdepartmental cooperation in the realization of foreign economic policy of the Republic of Uzbekistan on bilateral cooperation with foreign countries, to form a mutually beneficial system between public and economic administration, local government, attract foreign investment and advanced technologies, to increase exports domestic goods and services, attract tourists from foreign countries, expand the transport and transit potential of the republic, as well as increase the efficiency of intergovernmental commissions (committees and working groups) are defined as a target of these measures. Of course, the activities of the intergovernmental commission to develop cooperation with foreign countries will serve to ensure the effectiveness of work in this area.

By classifying the legal framework of bilateral cooperation of the Republic of Uzbekistan with the Gulf countries on the subject of regulation, it is possible to analyze the effectiveness of the legal framework of cooperation in most economic spheres. According to this analysis, there are more than 90 agreements between Uzbekistan and the Arab states in the Gulf region, most of which are intergovernmental, intergovernmental and interagency agreements of economic nature. Analyzing the agreements in terms of periodic development, it became clear that the agreements in the economic sphere, most of which were signed from the years of independence to 2015 .

Since the years of independence, during the period of 1992-2015, a solid legal basis for cooperation in the economic sphere was established. At the same time, the signing of agreements on the establishment of investment companies is particularly relevant. 


\section{Effectiveness of International Documents on Bilateral International Cooperation of The Republic of Uzbekistan With The Gulf Countries}

For example, an agreement signed in 2009 between the Fund for Reconstruction and Development of the Republic of Uzbekistan and the General State Reserve of the Sultanate of Oman on the establishment of a joint investment fund with a charter capital of \$ 500 million. $75 \%$ of the shares of this charter fund belong to the Government of Oman and $25 \%$ to the Government of Uzbekistan. Today, the Uzbek-Oman Investment Fund is one of the largest funds in Uzbekistan. The company decided to expand its investment portfolio by covering the stock market of the Republic of Uzbekistan by creating a securities fund.

Another such treat is the agreement on the establishment of a joint investment company Uzemiratholding. This agreement was signed by the Government of the Republic of Uzbekistan, the Fund for Reconstruction and Development of the Republic of Uzbekistan and Dubai Holding with a charter capital of \$ 1.25 billion. $80 \%$ of the fund is provided by Dubai Holding and $20 \%$ by the Fund for Reconstruction and Development of the Republic of Uzbekistan. The purpose of the joint investment company Uzemiratholding is to attract investment activity in the country and abroad, as well as to attract foreign direct investment to Uzbekistan.

The trade turnover between the Republic of Uzbekistan and the United Arab Emirates in 2007 amounted to 93.1 million US dollars and in 11 months of 2018 -

124 million US dollars [3]. These types of agreements contribute to the investment potential of the Uzbek economy, and investments are directed to relevant areas such as infrastructure, transport and logistics, the establishment of enterprises. In this regard, in paragraph 12 of the tasks set out in the Address of the President of the Republic of Uzbekistan to the Oliy Majlis of December 28, 2018 is planned to approve the proposal of the Fund for Reconstruction and Development of the Republic of Uzbekistan, the State Committee for Investment, the Ministry of Finance, the Fund for Reconstruction and Development of the Ministry of Economy and Industry of the Republic of Uzbekistan and the Abu Dhabi Development Fund (UAE) to establish a joint Uzbek-UAE investment company (hereinafter - the investment company) [4]. It is important to continue effective cooperation within the activities of these funds. It is important to expand the production capacity of the country, as well as attract foreign direct investment and innovative technologies to further enhance the competitiveness of the economy and improve the relevant legal framework. The Ambassador Extraordinary and Plenipotentiary of Saudi Arabia to Uzbekistan said, that during this period (2005-2015), despite the development of economic and investment, cooperation between Uzbekistan and Saudi Arabia, the volume of trade turnover between Saudi Arabia and Uzbekistan was insufficient [5]. In general, the volume of trade with the countries of the region with huge economic potential was not satisfactory. Russian scientists E.M. Savicheva and M.O. Shaar also noted that the volume of trade turnover of Uzbekistan with the Arab states in the Persian Gulf is not so developed [6].

Analyzing other types of intergovernmental agreements signed during this period, we observed that most of them are related to the investment sector. In particular, the agreement between the governments of the Republic of Uzbekistan and the Sultanate of Oman on the construction of a library of the Institute of Oriental Studies named after Abu Rayhan Beruni of the Academy of Sciences of the Republic of Uzbekistan and scientific and cultural cooperation in Tashkent. Under this agreement, the library will be funded by the government of the Sultanate of Oman [7]. The opening of this building took place on March 15, 2018. Today, the collection of unique manuscripts of the Institute of Oriental Studies named after Abu Rayhan Beruni is included in the UNESCO World Heritage List.

According to the Memorandum of Cooperation between the Government of the Republic of Uzbekistan and the Kuwait Fund for Arab Development [8], the Kuwait Fund participates in the financing of specific projects in the form of soft loans as a financial instrument. The loan agreement between the Republic of Uzbekistan and the Kuwait Arab Development Fund for the provision of medical equipment to 171 emergency departments of the city and district central hospitals is an effective result of the above agreement. On the basis of this agreement, the President of the Republic of Uzbekistan adopted a resolution on measures to equip emergency departments of central district and city hospitals with medical equipment, which will be implemented with the participation of the Kuwait Fund for Arab Economic Development.

According to our research, investments made by Arab Development Funds have been mainly focused on improving infrastructure, construction and development of the economy, and have shown effective results. The implementation of bilateral agreements between states is an example of their legal effectiveness. Based on the effectiveness of the above-mentioned agreements, we believe that long-term and low-interest loan agreements will still bring positive results today.

In general, in the years since 2016, cooperation with the above-mentioned Arab Development Funds has intensified. Effective "roadmaps" have been developed for existing agreements between states, and the legal framework between the countries under study has been further expanded. For example, during the official state visit of the President of the Republic of Uzbekistan Sh. Mirziyoyev to the United Arab Emirates, a total of 10 agreements were signed, including 5 interstate and intergovernmental agreements, and 5 interdepartmental agreements. The total economic value of these contracts is more than 10 billion US dollars. An action plan has been developed for the implementation of the signed agreements. Also, adopted the Presidential Decree "On organizational measures to attract financial and technical assistance from the United Arab Emirates to increase the efficiency of public administration of the Republic of Uzbekistan" [9]. 


\section{Effectiveness of International Documents on Bilateral International Cooperation of The Republic of Uzbekistan With The Gulf Countries}

Another aspect of the effectiveness of the recent agreements is the implementation of the agreement signed between the Government of Uzbekistan and the Mubadala and Masdar Abu Dhabi investment companies. The Ministry of Investment and Foreign Trade, Thermal Power Stations JSC and Mubadala Investment Company in Abu Dhabi (UAE) have signed an agreement on privatization and development of the Talimarjan thermal power plant. The agreement provides for the privatization of existing power units and the construction of new energy units. The mechanisms and conditions of privatization, development, financing and operation of the energy sector are also defined. According to the document, Masdar (a subsidiary of Mubadala) will design, finance, build and commission a wind farm. The investment in construction is estimated at $\$ 600$ million [10].

According to Russian orientalist scientist V. Isaev, the United Arab Emirates is interested in investing in Uzbekistan in three main areas. "First and foremost, the UAE is interested in investing in the oil and gas sector. Today, the republic does not have sufficient capacity to transit gas to countries such as China and Tajikistan, while the UAE has sufficient financial resources and technology to implement such projects. It also interested in the textile industry and the modernization of high-quality raw material processing enterprises" [11].

While acknowledging Isaev's views, we believe that while acknowledging the potential of the existing oil and gas reserves in Uzbekistan today, it is necessary to study the experience of Arab countries in exploration technology. It is also necessary to improve the effectiveness of existing agreements in the oil and gas sector and to form a legal framework for cooperation with countries in the region in this area.

\section{CONCLUSION}

The effectiveness of the legal framework of Uzbekistan and the Gulf countries can be justified in the sectors of the economy, the allocation and implementation of loan agreements and grants by the funds for various projects. At present, in order to develop economic cooperation, it is expedient to create a favorable investment climate for investors, to improve the working mechanism of the adopted laws.

We believe that there are not so effective results in the field of education and science in the social sphere among the countries under study today. It is necessary to expand the base of contracts in the social sphere, increase the effectiveness of existing legal frameworks. In this regard, it is necessary to develop cooperation between universities of the two countries, strengthen cooperation in innovative, technical areas of education, conduct research. Also, the number of visits of tourists from Arab countries to Uzbekistan in the field of tourism in the social sphere does not reflect the average figure. However, despite the fact that Uzbekistan is a country of great destinations, it is able to attract tourists with the reforms being carried out in our country for the development of Islam and the unique view of the nature of our country. In order to further increase the number of Arab pilgrims to Uzbekistan, it is necessary to further develop programs in the areas of "Halal" tourism, "Pilgrimage tourism". We also believe that increasing the flow of UAE visitors to seasonal hunting tourism should systematize the industry, creating appropriate convenience for visitors to this type of tourism.

\section{REFERENCES}

1) Gavrilov V.V. International and national legal systems: the concept and main directions of interaction // Abstract of the dissertation for the degree of Doctor of Law. - Kazan, 2006.

2) On measures to further improve the activities of the Uzbek parts of intergovernmental commissions (committees, councils and working groups) on bilateral cooperation between the Republic of Uzbekistan and foreign countries // PP - 4331, 23.05.2019/

https://www.norma.uz /novoe_v_zakonodatelstve/kak_opredelyaetsya_effektivnost_dvustoronnih_otnosheniy

3) 3.Uzbekistan and the UAE agreed on cooperation in the field of labor resources // https://podrobno.uz/cat/obchestvo/uzbekistan-i-oae-dogovorilis-o-sotrudnichestve-/

4) 2017-2021 yillarda Uzbekiston Republicsini rivojlantirishning beshta ustuvor yunalishi buicha harakatlar strategy sini "Faol investmentlar va ijtimoiy rivozhlanish yili"da amalga oshirishga oid davlat dasturi // ID-1678/ https://regulation.gov.uz/

5) Abdurahmon bin Abdullah al-Shae: Uzbekistan and Saudi Arabia have unused reserves in cooperation // https://podrobno.uz/friends/interwu\%3A+posol+ksa/

6) Savicheva E.M., Shaar O.M. Relations of the Arab countries of the Persian Gulf with the Central Asian states of the CIS. $-\mathrm{P} .163$

https://cyberleninka.ru/article/n/otnosheniya-arabskih-stran-persidskogo-zaliva-s-tsentralno-aziatskimi-gosudarstvamisng/viewer

7) Uzbekiston Respublikasi bilan Omon Sultonligi hukumatlari y̆rtasida Toshkent shahrida Uzbekiston Respublikasi Fanlar Academiyasi Abu Raihon Beruniy nomidagi Sharkshunoslik institute kutubkhonasini qurish va ilmiy-madaniy hamkorlik tugurisidagi Bitimning 2-moddasi. 
Effectiveness of International Documents on Bilateral International Cooperation of The Republic of Uzbekistan With The Gulf Countries

8) Mazkur Memorandum Quwaitning Al-Quwait shahrida 19.01.2004 sanasida imzolangan va kuchga kirgan.

9) Konun huzhzhatlari malumotlari milliy bazi, 06/25/2019, 08/19/5480/3330-son.

10) https://uz.sputniknews.ru/economy/20200127/13315980/Talimardzhanskuyu-TES-privatiziruet-kompaniya-iz-OAE.html

11) Isaev V.V. What is the interest of the United Arab Emirates (UAE) in Central Asia

// https://tzh.sputnikneshs.ru/radio/20190325/1028545434/ orientalist-why-uae-invest-central-asya.html

There is an Open Access article, distributed under the term of the Creative Commons Attribution - Non Commercial 4.0 International (CC BY-NC 4.0)

(https://creativecommons.org/licenses/by-nc/4.0/), which permits remixing, adapting and building upon the work for non-commercial use, provided the original work is properly cited. 